\title{
THE AMERICAN JOURNAL
}

\section{OF \\ SEMITIC LANGUAGES AND LITERATURES}

(CONTINUING HEBRAICA)

Volume XXIII

APRIL, 1907

NUMBER 3

\section{THE STORY OF THE THREE YOUTHS}

\author{
By C. C. Torrey \\ Yale University
}

\section{ORIGIN OF THE STORY}

Among the most interesting surviving specimens of old Semitic literature must be counted the story of the three young guardsmen at the court of King Darius, and their contest of wits in the royal audience hall. As has already been shown (this volume, pp. 123-35), this narrative was originally written in the Aramaic language, and was interpolated in the Chronicler's history of Israel by an unknown hand, probably near the beginning of the second century B. c. The main questions as to its origin, date, and primitive form, and the class of literature to which it belongs, remain to be answered.

The interpolator, as was shown (see pp. 130-32), gave the story, in the main, as he found it, without attempting to work it over, or indeed to make any alteration whatever beyond what was absolutely necessary. The beginning, obviously, was left untouched. Up to the end of $4: 42$, moreover, there is not a clause, nor even a word, that seems to be secondary or editorial, excepting of course the manifest gloss in 4:13. It was only at the end, where the story required to be adapted to a definite place in Jewish history, that redactional patches were necessary, and were made. The interpolator himself did this harmonistic work; and one 
necessary feature of it was the occasional change of the name "Cyrus," in the immediately following portion of the Chronicler's history, to "Darius" (above, pp. $132 \mathrm{f}$.). The presence of the name "Darius," in fact, was an indispensable condition of the insertion of the story, Zerubbabel being the hero. The question therefore arises at once, whether the interpolator may not himself have introduced the name throughout the whole story. We know with certainty that according to his representation the king who sent Zerubbabel and his company to Jerusalem was Darius II Nothus $;{ }^{1}$ but it is quite another question, whom the author of

$1 \mathrm{It}$ is strange that the question of the chronological order of the Persian kings according to the attested Jewish tradition should have made, and should still be making, so much trouble among scholars. See for example Meyer, Entstehung des Judenthums, p. 14; Wellhausen, Israelitische und jüdische Geschichte ${ }^{5}$, p. 171, note; Bertholet, Esra und Nehemia, p. 13, middle. The simple fact is this, that according to the accepted view of the Jewish scholars and writers, in the Greek period and still later, a kingdom of the Medes preceded that of the Persians, and Darius I Hystaspis was the monarch of this Median kingdom. Aside from this one important error, the Jewish writers made no mistake in regard to the Persian kings, but everywhere preserved the true order.

As for the kingdom of the Medes, it is the one briefly referred to in Dan. 2:39 and $7: 5$, as scholars are generally agreed. Neither the author (or authors) of Daniel nor any of the other Jewish writers shows any interest in this Median power or its history. The duration of its rule over Babylonia was believed to have been very brief; to have included, in fact, the reign of only one king. We read in Dan. $5: 30,6: 1$, that upon the death of the last Babylonian king, Belshazzar, his kingdom was taken by Darius "the Mede;" and we are told with equal distinctness in $6: 29$, cf. $9: 1,10: 1,11: 1$, that this Darius was immediately succeeded by Cyrus, the first king of the Persians. (I do not believe that the original text of Dan. 9:1 called this Darius the "son of A h a suerus." The name who substituted a well-known name for the unknown, and probably corrupt, form which lay before him. In Josephus, the name is "Astyages." One might perhaps conjecture "Cyaxares" ( $\mathrm{H}$ uwa h̆ š t a r a), for this blunder would at least have involved no anachronism. Cyaxares flourished about 600 B. C., and this Darius came to the throne "about sixty-two years of age" (Dan. 6:1). But perhaps we need not take the writer's chronology so seriously. I suppose it is possible that the author, or authors, of these chapters had never heard the name of Hystaspes.) That is, in the Jewish tradition represented by the author of Daniel (who was a man of some learning), Darius I Hystaspis was put immediately before Cyrus instead of immediately a f e r him. The author of Daniel would have begun his list of the Persian kings with the names: Cyrus, Xerxes, Artaxerxes I Longimanus, Darius II Nothus, etc.

The Chronic ler's history of Israel represents precisely the same view of the royal succession, and, accordingly, of a brief Median rule preceding the Persian. It is perfectly plain from Ezra 4:1-7 that his list of the Persian kings began in the same way as did that of the author of Daniel. The Chronicler makes no mention of Darius Hystaspis, "The Mede," before Cyrus, for the same reason that he fails further on to include Artaxerxes III Ochus, namely, because these kings (as he supposed) had nothing to do with the history of the Jews. But aside from this one transposition of Cyrus and Darius-the same which is made in Daniel-his succession of Persian kings, as given in Ezr.-Neh., is the correct one. According to his view, Zerubbabel and his companions finished the temple under Darius Nothus; and the Artaxerxes who befriended Ezra and (afterward) Nehemiah was Artaxerxes Mnemon.

Again, the Chronicler's Aramaic source represents the selfsame historical tradition. The author of this story of the building of the temple of course makes no mention of the Median king who preceded Cyrus, nor does he have occasion to mention Xerxes; but he leaves us in no doubt as to the fact that, in his belief, the temple was finished in the time of the Darius whose reign followed that of Artaxerxes I.

The textual tradition, it should be observed, perpetuates this view of the two kings named Artaxerxes. The name of the enemy of the Jews, who is mentioned in Ezra 4, is invariably written with t the name of the friend of the Jews, mentioned in Ezra $7 \mathrm{f}$. and 
the Story of the Youths intended by his "Darius," or indeed, whether he used this name at all. What, then, is the historical setting of the story, and who is the "king" at whose palace the scene is laid?

It is, of course, beyond question that the story was originally told of a king, not of a satrap, governor, or other high official. It is almost equally certain that the scene was laid in Persia. From the beginning of the story to its end, the Persian kingdom and its capital are plainly in the thought of the writer. The allusions are too many and too deeply imbedded in the structure of the story to be regarded merely as the result of an editorial revision (see, for example, 3:1, 2, 9, 14). We must conclude that when the story was originally composed the narrator intended to describe a scene at the court of one of the Achaemenids. Observe also how the interpolator takes it for granted that the event described took place in the Persian capital. If he were giving the tale a new setting, he would certainly be explicit as to the name of the city; but as it is, he plainly assumes that every reader would know that Susa was intended. Thus, in 4:57: "And he (Darius) sent away all the vessels which Cyrus had brought ${ }^{2}$ from Babylon (i. e., to Susa);" and again, in verse 61: "So he (the youth) took the letters, and came forth (from Susa) to Babylon."

If no other evidence were to be had, it would still remain doubtful whether the name "Darius". is also original, or whether it is to be ascribed to a later hand. But fortunately, we have the evidence which is needed. Thanks to that most important verse, $4: 29$, we are able to determine which king is intended, and the

Neh. 2, is invariably written with $\circlearrowright$. The Darius who came between these two kings was of course Darius Nothus.

And finally, the interpolator of the Story of the Youths shared the view of the Chronicler, the author of Daniel, and the textual tradition of Ezr.-Neh. The fact that he transposed the account of the correspondence in the reigns of Xerxes and Artaxerxes, Ezr. 4:6-24, to the place which it occupies in I Esdr. is conclusive evidence of this. Like the other Jewish writers of his time, he believed that the Darius under whom Zerubbabel finished the building of the temple was Darius Nothus; and, according to him, it was at or very near the beginning of the reign of this same king that the three youths held their contest at the Persian court. According to his version of the history, Zerubbabel was still a youth at the time of the completion of the temple; while according to the ('hronicler's version he was an old man at that time (though in all probability the Chronicler supposed the reigns of Xerxes and Artaxerxes I to have been brief ones).

It is true that ou modern historians may reasonably be in doubt as to the date of the completion of the temple; but it does not seem to me that there is justification for doubt, in the face of this evidence, as to what view the old Jewish narrators held.

2 The Greek translator's é $\chi \omega ́ \omega \iota \sigma \epsilon \nu$ is probably a mistaken rendering, both here and in verse 44 ; see the notes. 
approximate date of the story. According to the text ordinarily used, the passage reads thus: ${ }^{3}$

I saw Apama the daughter of Bartakes, . . . the concubine of the king, sitting at the king's right hand; I saw her snatch the crown from his head, and place it upon her own; with her left hand she slapped the king. In spite of all this, the king gazed upon her with open mouth.

It is obvious that we have here the key to the date and original home of the story. The proper name A pama, at least, has been correctly transmitted. It is a very well-known name, and yet not one that would have been chosen at random or taken as typical. The writer of the story had a real personage in mind at this point. The fact that the name of the girl's father is appended adds to the certainty of this conclusion, though the latter name is so badly mutilated as to seem almost hopeless.

Among all the women named Apama who are known to us, there are only two who need to be taken into account. The prime requisite is that the girl should have been a concubine, or at least a favorite, ${ }^{4}$ of one of the Persian kings. The two who most nearly meet the requirements are (1) Apama, the daughter of the satrap Artabazos III, who was the son of the satrap Pharnabazos II; and (2) Apama, the daughter of the Bactrian satrap Spitamenes, or Pithamenes. These two Apamas were the most celebrated of all who bore the name, and both made their first appearance in history at the court of the Persian king. The king, moreover, was Darius III Codomannus, and this fact is another corroborating element. The coincidence is too far-reaching to be an accident; the natural conclusion is that the king originally intended in this story was Darius III. All that we know of the two Apamas, during their early life in Persia, is contained in the well-known story of the great feast at Susa, given by Alexander to his generals after the conquest of Persia. At this feast, according to the historians, Alexander gave to the foremost of his generals wives from the Persian court. Apama, daughter of Spitamenes (or, as some authorities have, Pithamenes), was given to Seleucus Nicator, the first of the Syrian line of monarchs; and Apama, daughter of Artabazos, was given to Ptolemy Lagi, the first of the Egyptian kings. Thus Arrian, Anabasis, vii, 4, 6,

3 The Greek text, with its various readings, will be given below and discussed.

4 We are left in some uncertainty by the Greek $\pi a \lambda \lambda a \kappa \eta$ here, inasmuch as it is a translation and we cannot be sure what Aramaic word was used in the original. 


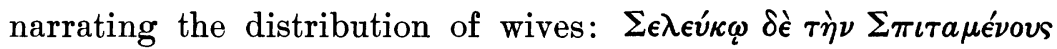

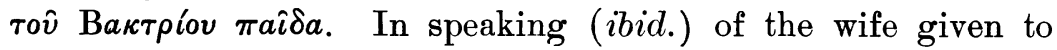
Ptolemy Lagi, he calls her the daughter of Artabazos, but uses the native name 'A

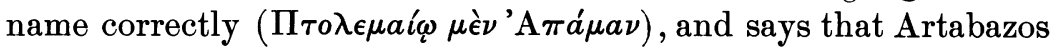
was her father. Strabo, Geographica, xii, 8, 15, confuses the two Apamas, saying that Apama, the daughter of Artabazos was given in marriage to Seleucus Nicator. ${ }^{6}$ The statement regarding Seleucus and his wife which is given by John Malalas, Chronographia, viii (Migne, Vol. XCVII, col. 312), is perhaps worth quoting:

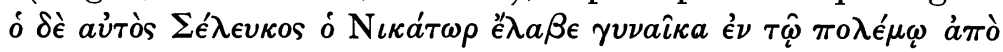

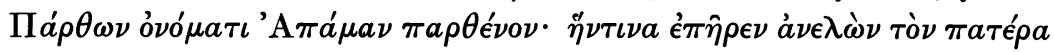

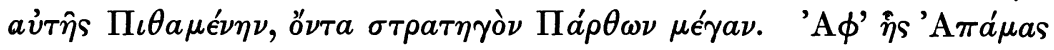

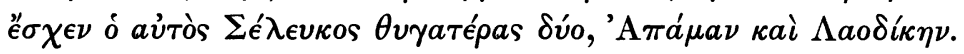

There is nothing in our extra-biblical sources to indicate that either the daughter of Artabazos or the daughter of Spitamenes had been, or was supposed to have been, a concubine of Darius Codomannus. This, however, is a fact of no importance. In I Esdr. 4:29 we are dealing, in any case, with a popular tale, the original purpose of which we have no means of knowing. Court gossip and the story-tellers of the common people alike love to play with such details as these, and to invent them, with or without malice prepense, especially when the early life of the royal personage was (as in this instance) a romantic one, and had been lived in a foreign land. And Alexander might well have been represented as finding extraordinary treasures in the harem of Darius. It may be that the author of the Story of the Youths himself added this touch of local interest to the scene he was painting, representing the celebrated queen of his land as having been, in her girlhood, a favorite of the great Persian king. Be that as it may, we need waste no more thought on the $\pi a \lambda \lambda a \kappa \eta$ of

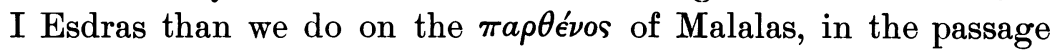
above quoted. Beyond question, the evidence within reach points to the general conclusions already stated: (1) the "Darius" of our story is, in any case, Darius III; (2) for the heroine of the verse 4:29, we must look either to Egypt or to Antioch.

5 See Wilcken, in Pauly's Real-Encyclopädie, s. v. "Apama."

${ }^{6}$ Noldeke, Gott. Gel. Anzeigen, 1884, p. 295, accepted the statement of Strabo, and was followed in this by Marquart, Fundamenta israelit. und judd. Geschichte, pp. $65 \mathrm{f}$. But the evidence inclines decidedly the other way (so also Wilcken, in Pauly, loc. cit.). 
It is not altogether easy to decide between the two Apamas; fortunately, the decision at this point need not greatly affect our conclusion as to the original home of the story. If the daughter of Artabazos and wife of Ptolemy is meant, then it is pretty certain that the tale was composed either in Egypt or in Palestine, somewhere near 300 в. C.; for such an allusion to the foreign-born queen could only have been made during her lifetime or a short time after her death. If the other Apama, the daughter of Spitamenes and wife of Seleucus, was intended, the natural conclusion would be that the story was written in Syria, and perhaps most likely in northern Syria, at about the same date. Of local "color," or allusion, to connect the narrative with either of the two kingdoms, there is not a particle. All the setting is distinctly Persian, as has already been remarked, and the Persian capital is the only scene which the story suggests. ${ }^{7}$ As for the use of the Aramaic language, we know that it was the reigning tongue at this time, from the borders of Persia to the Mediterranean, and that it was also used to some extent in Egypt, where the Semitic element of the population was considerable. Still, a document of this sort, composed in Egypt at the beginning of the third century B. C., would probably have been composed in Greek ; in Syria or Palestine, on the contrary, Aramaic would have been the natural vehicle. So far as general probability is concerned, then, the matter stands thus: if our "Apama" is the Egyptian queen, then the story is most likely to have been written in Palestine; if the wife of Seleucus is intended, then it probably originated somewhere in central or northern Syria.

The main hope of reaching a satisfactory decision lies in the names which are given in 4:29. These, as has already been remarked, are presumably corrupt in the forms which have reached us. Foreign proper names in a Semitic text are easily and rapidly changed. The transliteration into Greek is apt to involve some additional loss, and the corruption is increased still further by copyists, especially when, as in this case, the original is no longer to be had for reference. All our texts and versions of I Esdras are derived as was shown above (p. 141), from the fragment of a single faulty Greek codex. It is only necessary to recollect the large number of almost incredibly distorted proper names else-

7 Marquart, op. cit., p. 66, attempts to show that the palace in Antioch was the original scene, but fails conspicuously at every point. 
where in this book, in order to see what we must be prepared to find here. And, in fact, our traditional texts of 4:29 do not contain any form closely resembling either Artabazos or Spitamenes. In the ordinary text of the Egyptian recension, represented by the uncials A, B, and their fellows, the Syro-Hexaplar version, the Ethiopic, and other less important witnesses, the girl Apama

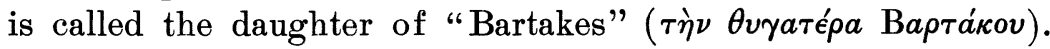
We seem to have conclusive evidence, however, that this was not the reading of the primal Greek fragment out of which "First Esdras" grew. In the Syro-Palestinian recension, found in

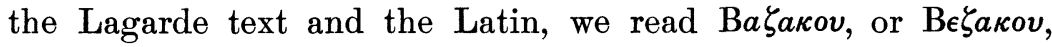
Lat. Bezacis; and as this reading is confirmed by the wit-

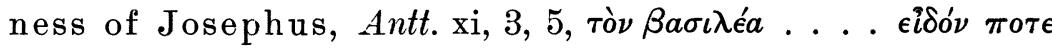

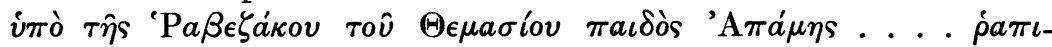
$\zeta o ́ \mu \epsilon \nu o \nu$, we must accept it as the original reading of our I Esdras fragment. For, (1) it is certain that all our I Esdras texts were derived from the one fragment; (2) Josephus, though he followed a Greek text in Ezr.-Neh., as elsewhere, did not have before him the mutilated scrap, "I Esdras," but a complete translation of the Chronicler's book; and (3) it is certain that no I Esdras text was influenced here by Josephus. The Syrian text of 4:29 is thus the original, so far as I Esdras is concerned, reading as follows:

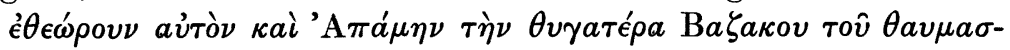

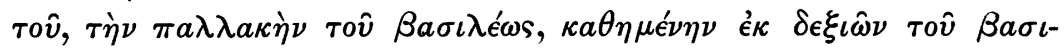
$\lambda \epsilon \in \omega s, \kappa \tau \dot{\epsilon}$.

From the form of the name given here, the other forms were derived, through the usual accidents of transmission. In the copying of cursive manuscripts the spelling Baprakov arose, prob-

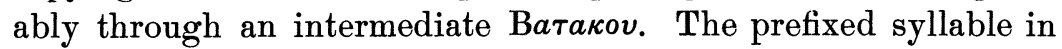
the reading of Josephus, $\mathrm{P} a \beta \epsilon \zeta a \kappa o v,{ }^{8}$ is merely the result of a very

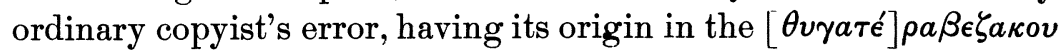
of the Greek text which was Josephus' only source. ${ }^{9}$

${ }^{\mathrm{A}} \mathrm{A}$ good deal of ingenuity has been wasted on these names. Fritzsche says of the form Rabezakes in Josephus, "das wăre השרבש:" Ball, in the Variorum Apocrypha, cites the Syriac, "Aphūma, daughter of . . . . rabba Artak," and remarks that the Greek Bartak-es may be a corruption of the latter. Marquart, Fundamente israelit. u. judd. Geschichte, pp. $65 \mathrm{f}$., seems to me to heap one improbability upon another in the attempt to explain the names in the verse. Regarding the Syriac "Artak," see below.

9 Notice that a blunder of exactly the same nature had found a place in the Greek text, belonging to the other (Egyptian) recension, which was translated by Paul of Tellä. [ $\theta v \gamma a-$

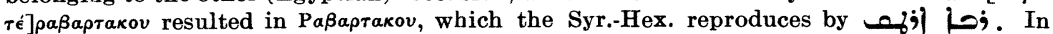
view of all the proper names and titles beginning with $R a b$-, it is no wonder that this mistake should have been made in more than one place. 
We are certainly justified, under the circumstances, in connect-

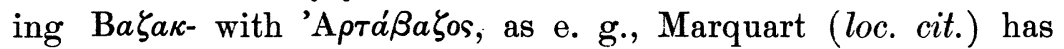
done. If we can suppose the original form of the name to have been Artabāzak (Marquart), the problem is at once made easy, for the hypothesis of a very ordinary sort of haplography in the

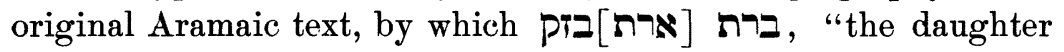

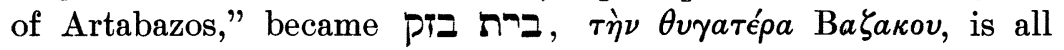
that is necessary.

But there is still another point at which the text of this verse in I Esdras is unsatisfactory. The rov $\theta a v \mu a \sigma \tau o \hat{v}$ must conceal a proper name, for the adjective would be altogether out of place either in Aramaic or in Greek. If a name originally stood here, it was presumably that of the grandfather of Apama; and in the text of Josephus we do, indeed, have such a name, rov $\Theta \epsilon \mu a \sigma i o v$. It is true that this does not appear to be a very desirable acquisition, inasmuch as it has seemed probable, since the researches of Nöldeke, that the father of Artabazos III was the satrap Pharnabazos II; still, it is not hard to believe that the narrator of this tale could have been mistaken in such a particular; and as

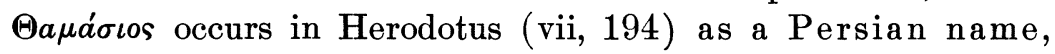
and this is the very form from which the other readings ( $\Theta \epsilon \mu a$ á $\iota \circ$,

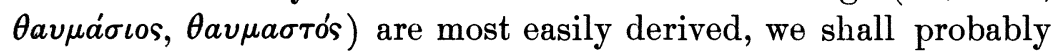
do well to retain it.

The conclusion is, that the heroine of I Esdr. 4:29 was Apama, the daughter of Artabazos ("son of Thamasios"?), and that the Story of the Youths was written probably while she was still living as queen of Egypt and Palestine, but possibly in the next following generation. The home of the story was Palestine, where the connection with Egypt was then very close, and where the Aramaic language was commonly employed, as we know, for compositions of this nature. Other minor indications, of very little weight in themselves, seem to me to point in the same direction: the freedom with which the writer uses the queen's name; his uncertainty (?) as to the name of her grandfather; and the fact that the first appearance of the story of which we have knowledge was in Judea. At the time when it was inserted in the Chronicler's narrative of the Jews (probably in the early part of the second century B. c.), Palestine was no longer under Egyptian rule, and queen Apama and her history were already forgotten.

It has already been observed (above, pp. $130 \mathrm{f}$.) that the original 
and unexpanded Story of the Youths does not extend beyond 4:42 in our book. It is complete as we have it; even at the end it does not appear that anything is missing; on this point see further below. There is no likelihood that it formed a part of a larger work; as it stands, it is a carefully planned and executed whole, and quite sufficient unto itself. Much might be written as to its literary character and qualities, for it is an admirable composition, but here there is space only for a few general observations.

The scene of the story is laid in Susa, shortly before the advent of Alexander, and it thus belongs to the great group of legends which attached themselves to this turning-point in the history of the East. The description of the king's surpassing power and glory is that with which we are familiar in the tales belonging to the "Alexander cycle." The narrators loved to represent the last Darius as the richest and most glorious of his line. This is exactly what was done, for example, in Dan. 11:2, a verse which is valuable as giving us the popular Palestinian view of Darius Codomannus: "And now I will show thee the truth. Behold, there will arise yet three kings in Persia, but the fourth will be far richer than all the others; and when he has become mighty in his riches, the Lord of All ${ }^{10}$ will raise up the kingdom of Yāwān" (i. e., the Seleucid kingdom, in the place of the kingdom of Persia).

There is nothing to show that the story originated in Jewish circles. Against a possible Jewish origin speaks the fact that no mention is made of the Jews or their institutions, from the beginning up to $4: 42$, which is at all events the last verse of the story in its original form which has reached us. ${ }^{11}$ Moreover, the religious element is almost entirely lacking, although the writer's main theme and the development of his thought were such that we should have expected him at least to introduce the mention of God before finishing his hero's discourse on the mightiest and best of all things. How sorely this lack was felt by the early translators is evident from the way in which they have introduced alterations and interpretations in the endeavor to bring in the

10 As I have shown elsewhere, the missing word של הכל is to be restored before. See my article, "Yãwān and Hellas as designations of the Seleucid Empire," JAOS, XXV, $310 \mathrm{f}$.

11 The fact that in 4:13 the words "this was Zerubbabel" are secondary is obvious enough. Moreover, it is a poorly executed gloss, for this on e $\mathrm{n}$ a me could not suffice to identify the man-hence the additions which we find in the Lagarde Greek, the SyroHexaplar version, and other texts. This perhaps makes it more probable that the interpolator himself inserted the name here; he had no need to be more explicit, since the new context of the story, and the subsequent gloss in $5: 6$, would more than suffice for the identification. 
missing religious element (see $4: 35,36,41$, and the notes on these verses). ${ }^{12}$ The author may indeed have been a Jew by birth; but this writing cannot be said to belong, in any true sense, to the Jewish national or religious literature; and the probability is strong that it was composed by a gentile. It is worthy of remark that it contains no allusion to, or quotation from, the Old Testament. The only passage which could be taken as possibly showing acquaintance with the Hebrew Scriptures is $4: 39$; but the resemblance to Deut. $10: 17$ is not striking, and is probably purely accidental.

This tale of the youths and their contest belongs to the popular "Wisdom Literature" of Syria and Palestine, written in the language and embodying the philosophy and the rhetoric of the time. There were doubtless many such writings, and it is by a stroke of rare good fortune that this one has been preserved to our day. The chief concern of its author, it is plain to see, is with the three "wise sentences" which were uttered. He has no personal interest in the "third youth," who gained the victory, and neither names nor describes him. He does not care especially for the narrative, but cuts it short at all points. His interest is in the three discourses, and the story is told solely for their sake. He does, indeed, give his dialogue a striking historical setting, combining the legends of the great king, and his magnificent court, with a local allusion that must have added considerably to the interest of his readers. But this is merely his literary art; for the history in itself he had no concern.

From the literary point of view, the successive discourses of the three youths are highly interesting. It is evident that the form in which they are cast is well studied; in their structure they doubtless follow the approved models of their time and place. It is a pity that we have not the original Aramaic, so that we might observe the finer points of style and phraseology. The Greek, to be sure, is a close translation, and so far as the framework of the discourses and the construction of their successive paragraphs are concerned, we are nearly as well off as we could be if we were in possession of the original. Neither in the ideas expressed nor in the garb in which they are clothed is there anything that could properly be termed "hellenistic." There is no

12 It is no wonder that they should have felt that this element $\mathrm{m} u \mathrm{~s} t$ be present, seeing that the speaker of these immortal words was no other than the great leader Zerubbabel, the builder of the temple! 
evidence of the influence of Greek literature or philosophy. In this fact we may perhaps find some corroboration of the conclusion reached above as to the original home of the story; for a writer of such conspicuous ability as this one, composing a work of this nature in either Egypt or northern Syria, after the beginning of the third century B. c., would probably have given evidence of his close contact with Greek thought.

One fact of especial interest, in the literary structure of the discourses proper, is the use of the line of three beats. Even under the disguise of the Greek translation, this can be recognized again and again, all through the composition, from $3: 17$ to $4: 40$. Thus, in the speech of the first youth, $3: 20:^{13}$ עתיר | לא דכיר מלכא ושננא. Or in the speech of his successor,

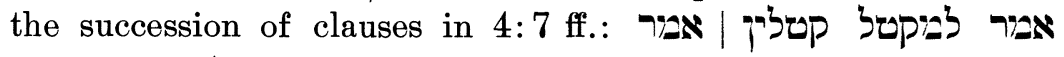

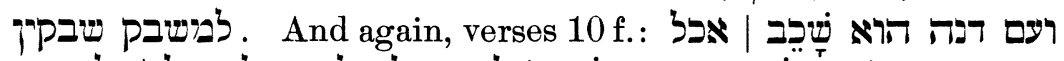

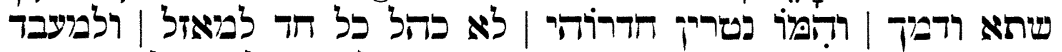
צבבידתא דילה | רצלוהי לא קאמליץ. The third youth begins his

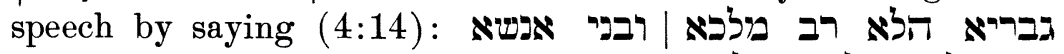

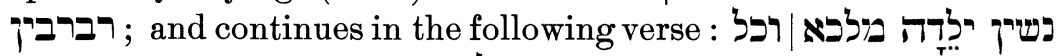
. עם די שלט בימא| ובארעא מנהן הוה , This is certainly not accidental; and the conclusion is, that the "standard" line of three beats, which appears everywhere in the Old Testament, is not a peculiar property of the Hebrew language or of the HebrewJewish sacred literature; but was the common poetic form, for compositions of every class, in Syria and Palestine, whether they were written in Aramaic or in Hebrew. This same conclusion had already been rendered probable by some passages in the Aramaic part of Daniel, to be sure.

In all likelihood, the Story of the Three Youths was popular in its own land while it still existed as a separate work. After it. became a part of a religious history, it found its way into other circles - and at the same time its original character and its true excellencies were lost to sight. The plainest example of its influence on a subsequent writing is found in the book of Esther. The literary relationship existing between the two has often been observed, but the conclusion is generally drawn, that I Esdras, being an "apocryphal book," must have been the borrower. Cornill, Einleitung ${ }^{4}$, p. 261, says that I Esdr. 3:1, 2 is a palpable

13 Of course the following specimens, chosen almost at random, are merely intended to give a general idea of the form of the original. Other wo rds than those chosen might often have been used. 
imitation ("eine handgreifliche Nachbildung") of Esth. 1:1-3. But these words must have been written without due consideration, for all the indications point just the other way. Imitation there certainly is. The book of Esther opens with the very same scene with which the Story of the Youths begins; a royal feast in the city of Susa, given to all the officers of the "hundred and twenty-seven provinces, from India to Ethiopia." Then the feast is described; but what had been told in our Story simply and soberly is here so exaggerated as to be merely grotesque. The festival in I Esdras is an affair of a single day; in Esther, the principal entertainment lasts one hundred and eighty days. Darius had feasted certain classes of his retainers, which are named; but "King Ahasuerus" makes a banquet for every human being in Susa, and the banquet lasts seven days. It is certainly not difficult to see on which side the borrowing lies.

The question of the literary relationship between I Esdras and Daniel is less easily settled. There is probably dependence, and the borrower was in that case certainly Daniel. In Dan. 6:2 we have the "hundred and twenty-seven ${ }^{14}$ provinces" of Darius' kingdom; and in the following verse the "three presidents," apparently the same who are mentioned in I Esdr. 3:9 as holding the highest position of authority under the king. The coincident use of these two items is not likely to be a mere accident $;^{15}$ the natural inference is that there was literary dependence (so also Marquart, op. cit., p. 68). Internal evidence then makes it certain that the borrowing, if borrowing there was, was by Daniel. The Darius of Dan. 6:1 ff., 29, is "Darius the Mede," who was put before Cyrus; from him, the Story of the Youths was as remote as possible. On the other hand, if we suppose that the author of Dan. 6 intended his king to be the same as the one who is mentioned in I Esdr. 3, we shall be driven to the conclusion that the borrowing took place before the Story of the Youths became incorporated in the Chronicler's history; for in our I Esdras, the king who befriended Zerubbabel came not only after Cyrus, but also after Xerxes and Artaxerxes I. This conclusion makes no difficulty for those who believe-as I myself have long felt certain - that the first six chapters of Daniel are

14 So the old Greek version, which here, as often elsewhere, has preserved the original reading.

15 Lagarde, as is well known, expressed the opinion (Mittheilungen, IV, p. 358) that the Story of the Three Youths originally stood in the book of Daniel, following Dan. 6:1. It is not surprising that he should have made few converts to this view. 
older than the rest of the book, and it seems to me to be probable, for every reason. ${ }^{16}$ It is not a necessary conclusion, however, for the author of Dan. 6:1 f. may have intended to represent his Darius as instituting customs which continued down to the time of the Persian king Darius Nothus.

After the Story became a part of the history of the Jews, interest was centered more on the three youths themselves than on the wise sayings which they uttered. As a matter of course, all three of them were soon believed to have been Jews. According to the Neapolitan Synopsis, for example (Lagarde, Septuaginta-Studien, II, p. 84), the two comrades of Zerubbabel on this occasion were Jeshua and Ezra. ${ }^{17}$ That which led to the preservation of the Greek Esdras fragment was, of course, not any regard for the true text (those who cared for the text would have been far more likely to destroy the fragment), or for the true course of the history; but solely the personal interest in Zerubbabel and the picturesque story of his life given in this document. For an illustration of the early Christian interest in this hero, see the Lucca old Latin codex (Lagarde, Septuaginta-Studien, II, p. 19, 3 ff.).

In the translation which here follows, the Story of the Three Youths has been separated from the interpolator's additions, and stands by itself once more, for the first time since 200 в. с. It is also treated for the first time as a translation from an Aramaic original, with an attempt to restore, as far as possible, the meaning of the primitive text. I do not believe that any one, reading the composition as it stands here, will deny to it a very high place in the literature of the ancient Semitic world. In translating the Story and, later on, the additions of the interpolator, I have followed Swete's text, not only because it is the most convenient, but also because it represents that recension of whose readings we are surest here. I have departed from it only in $4: 29$, for reasons already given. In a preceding chapter (above, pp. $128 \mathrm{ff}$.) I introduced some evidence showing that our Greek is a rendering of an Aramaic text; many more proofs of the same nature will be found in the notes appended to my translation.

16 The Story was interpolated in the book of Ezra somewhere near the beginning of the second century B. c., in all probability. If the old Greek translation of Chron.-Ezr.-Neh. really lay before Eupolemus, in the $\mathrm{middle}$ of that century (see Schürer, Geschichte des jiud. Volkes ${ }^{3}$, III, 311, 352 f.), there can be little doubt that it was the s a me translation from which our "I Esdras" fragment was derived.

17 Ezra and Zerubbabel not infrequently appear together in this way. In the Chronicle of John of Nikiū (ed. Zotenberg, pp. 169, 391) the two are identified. 


\section{TRANSLATION}

(I Esdr. 3:1-4:42)

$\mathbf{3}^{1}$ King Darius made a great feast for all his retainers; namely, ${ }^{a}$ all the members of his household, all the nobles of Media and Persia, ${ }^{2}$ and all the satraps, captains, and governors under his rule, from India to Ethiopia, in the hundred and twenty-seven provinces. ${ }^{3}$ And they ate and drank, and when they were sated they went away. Darius the king also retired to his bed-chamber and slept.

${ }^{4}$ Then stood on the watch ${ }^{\mathrm{b}}$ the three young guardsmen who protected the person of the king. And they said to one another: ${ }^{5}$ Let each one of us name a thing which is mightiest; ${ }^{c}$ and to him whose sentence shall seem wisest, Darius the king shall give great gifts and magnificent honors, ${ }^{\mathrm{d}}{ }^{6}$ namely, ${ }^{\mathrm{e}}$ permission to be clothed in purple, to drink from gold and to sleep upon gold, (to ride in) a chariot with a golden bridle, and (to wear) a tiara of fine linen, and a chain about his neck; ${ }^{7}$ and he shall sit next to Darius because of his wisdom, and shall be called Darius' kinsman. ${ }^{8}$ So they wrote each his own sentence; and having sealed the writing they put it under the pillow of Darius the king, saying, ${ }^{9}$ When the king awakes, the writing shall be given ${ }^{f}$ to him; and whose sentence is adjudged by the king and the three lords of Persia to be the wisest, to him shall be awarded the victory, as prescribed. ${ }^{10}$ The first wrote, Wine is mightiest. ${ }^{11}$ The second

a The $\urcorner\left(=\kappa a l 2^{\circ}\right)$ is either explicative (cf. the note on vs. 6) or secondary. It is sufficiently obvious, even without the comparison of Esther 1:3, that

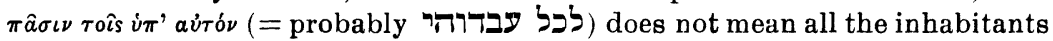
of the Persian realm. The enumeration which follows proceeds from the highest to the lowest of those who were invited. Whether or not the trans-

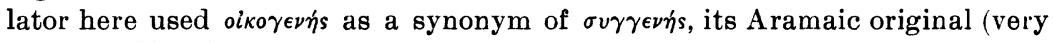
likely (בני ביתה) certainly meant more than "house-servants"!

${ }^{b}$ See the suggestion for emendation of the A ramaic text which was made

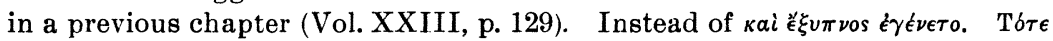

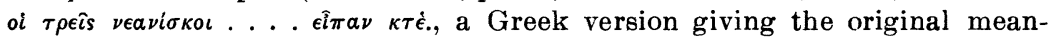

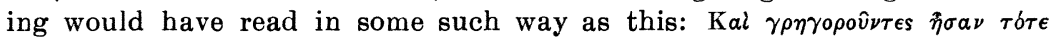

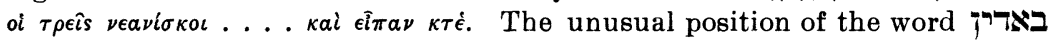
(= $\tau \delta \tau \epsilon)$ was probably the cause of the misunderstanding (or corruption) of the Aramaic text.

"Or, "Let each one of us frame a sentence, (declaring) what thing is mightiest." In any case, our Greek is a mistranslation; see Vol. XXIII, p. 129.

d The original probably had here a derivative of 2 .

e Apparently another explicative 1. Cf. the note on vs. 1.

${ }^{\mathrm{f}} \Delta \dot{\omega} \sigma o v \sigma \iota \nu$ auj $\tau \hat{\psi}$ : the favorite idiom in Aramaic, employing the indefinite third person plural in the place of a passive. 
wrote, The king is mightiest. ${ }^{12}$ The third wrote, Women are mightiest; but Truth is victor over all things.

${ }^{13}$ So when the king awoke, they took the writing and gave it to hin, and he read it. ${ }^{14}$ And he sent and summoned all the nobles of Persia and Media, and the satraps, captains, governors, and magistrates; ${ }^{a}$ and when they had seated themselves ${ }^{\mathrm{b}}$ in the hall of audience the writing was read before them. ${ }^{15}$ And they said, ${ }^{c}$ Call the youths, and they shall expound their sentences. So they were summoned and came in. ${ }^{16}$ And they said to them, Discourse to us concerning the things which you have written.

Then the first, who had declared the power of wine, proceeded ${ }^{\mathrm{d}}$ to speak as follows: ${ }^{17}$ Sirs, how mighty a thing is wine! It seduces the wit of all who drink it; ${ }^{18}$ It makes of one mind the king and the orphan, the slave and the freeman, the poor and the rich. ${ }^{19}$ It turns every mood into gaiety and glee; of distress, or of debt, there is no recollection. ${ }^{20} \mathrm{It}$ makes all hearts feel rich; there is no remembrance of king or satrap; the discourse is all in talents. ${ }^{21}$ Those who have drunk forget friend and brother, and erelong swords are drawn; ${ }^{22}$ then, when they wake from the wine, they remember not what they have done. ${ }^{23}$ Sirs, is not ${ }^{\mathrm{e}}$ the wine mightiest, since it can thus compel? When he had thus spoken, he ceased.

$4^{1}$ Then the second youth, who had declared the power of the king, spoke ${ }^{f}$ as follows. ${ }^{2}$ Sirs, are not men mighty, since they rule the land and the sea, and all that is in them? ${ }^{3}$ But the king is mightier still, for he is their lord and master; in all that he commands them they obey him. ${ }^{4}$ If he orders' them to war with

${ }^{a}$ Compare the enumeration of officers in Dan. 3:2, where the first four titles, in the old Greek translation, are the same and in the same order as here.

${ }^{\mathrm{b}}$ Read $\epsilon^{\prime} \alpha \dot{\theta} \theta \sigma a \nu$, plural, with the Latin, Syriac, Ethiopic, and the following context.

c Read $\epsilon i \pi a \nu$, plural, with the Syriac and vs. 16.

d The use of $\eta{ }^{\prime} \xi a \tau o$ in this narrative (also $4: 1,13$; cf. further 4:44, where

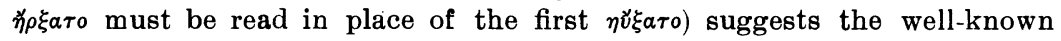
Aramaic usage, in which a conventional and often almost meaningless is prefixed to the narrating verb. See Dalman, Die Worte Jesu, p. 29; J. H. Moulton, Grammar of New Testament Greek (1906), I, 15.

e Compare the rhetorical question introduced by דִ דָ in Dan. 4:27, where Theodotion's translation has oủ $\chi$, as here.

${ }^{f}$ Concerning $\tilde{\eta} \rho \xi \alpha \tau$, see the note on $3: 16$.

g E $\pi$ in for the Aramaic רא, "command." 
one another, they do it. If he sends them out against the enemy, they go, and overcome mountains, walls, and towers. ${ }^{5}$ They slay, and are slain, but the king's command they transgress not. If they conquer, they bring all the booty to him; and when they make raids for plunder, whatever they take ${ }^{a}$ is his. ${ }^{6}$ They also, in turn, who serve not as soldiers, who go not to war, but cultivate the soil; as often as they sow, of the harvest they carry to the king; yea, each constrains his fellow to bring tribute to the king. ${ }^{(7)}$ And yet he is one man only. ${ }^{b} \quad{ }^{7}$ If he orders to slay, they slay; if to spare, they spare; if to smite, they smite. ${ }^{8}$ If he orders to lay waste, they lay waste; if to build, they build. ${ }^{9}$ If he orders to cut down, they cut down; if to plant, they plant. ${ }^{c}{ }^{10}$ All his people and his armies obey him. He, furthermore, reclines; he eats and drinks, and then sleeps; ${ }^{11}$ but they keep watch round about him; no one may depart to do his own work, nor may any oppose his will. ${ }^{12}$ Sirs, how shall not the king be mightiest, since he is thus obeyed? And he ceased.

${ }^{13}$ Then the third, who had spoken of women, and of truth (this was Zerubbabeld) took upe the word. ${ }^{14}$ Sirs, is not the king

${ }^{a}$ It is quite possible that $d \lambda \lambda a$ correctly represents the original Aramaic text; but if this is so, the writer at least expressed himself awkwardly. As Fritzsche observes, the ancient versions and copyists, as well as modern translators, have been troubled by this clause. It may be that the original contained a form derived from the root "take, seize," instead of one from רז, "other."

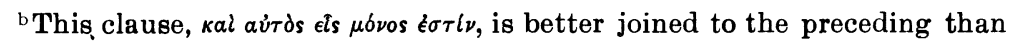
to the following verse. So far as the Greek is concerned, it might be connected either way, though the reading of the Lagarde text seems to join it to the preceding. Our present verse-division here is due to the influence of the Latin translation; the other versions are non-committal. Such translations as that of Guthe, "Er allein ist einzig!" (following Fritzsche) miss the true meaning. The Aramaic could not have expressed such an idea in these words. The

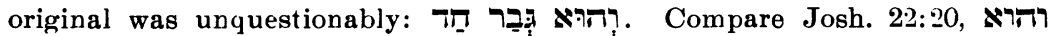
, איש אחד, where the Greek renders by kai oîros eis $\mu$ bovos. With the phrase as used here cf. Judith 1:11, where it is said that the rebellious nations did not

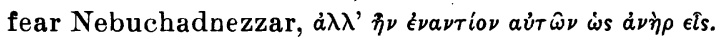

c These sentences, vss. 7-9, have a decidedly Aramaic sound. This persistent omission of conjunctions and conditional particles, after the opening clause, would be less likely in Hebrew.

dThese words were not in the original story, which made no mention of the Jews. The gloss was added either by the one who interpolated the story in the Chronicler's history, or by a still earlier hand.

e See the note on 3:16. 
great; and are not the sons of men mighty; $;^{a}$ and the wine, is it not powerful? Who now is it that rules all these, that governs them, is it not woman? ${ }^{15}$ Of woman the king was born; and all the people who rule the sea and the land ${ }^{(16)}$ were born of women. ${ }^{b}$ ${ }^{16}$ They nourished the men who planted the vineyards whence the wine comes. ${ }^{c}{ }^{17} \mathrm{It}$ is they who give grace to mankind, ${ }^{\mathrm{d}}$ and without them men could not live. ${ }^{18}$ If men have gathered gold and silver, and aught else precious, and see a woman comely in form and feature, ${ }^{\mathrm{e}}{ }^{19}$ leaving all this they gape at her, and with open mouth they gaze upon her; yea, all choose her above gold and silver and everything precious. ${ }^{20} \mathrm{~A}$ man forsakes his own father, who brought him up, and his native land, and joins himself to his wife; ${ }^{21}$ to her he abandons himself, ${ }^{f}$ and remembers not father, nor mother, nor country. ${ }^{22}$ Hence also you may know ${ }^{g}$ that women rule you: do you not labor and toil, and then bring all and give it to women? ${ }^{23} \mathrm{~A}$ man takes his ${ }^{\mathrm{h}}$ sword, and goes forth to

a $\Pi$ II $\lambda$ ol is an obvious mistranslation of רברבין. Cf. vss. 2 and 15; the meaning "mighty" is absolutely necessary.

${ }^{b}$ On the relation of the Greek translation to the Aramaic text of these

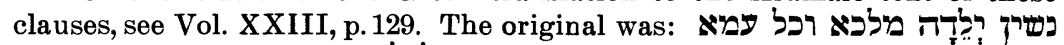

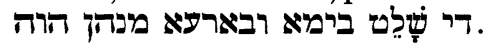

cIn the Syriac (Hexaplar) version, instead of lor مصنز is attested by all the MSS, the reading should be lor

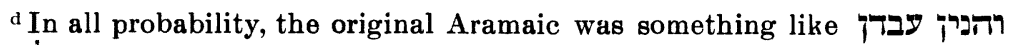
הדרדר לאמשטא . The object of the verb was a word which meant "adornment," and could be understood in either one of two ways; see my note in Vol.

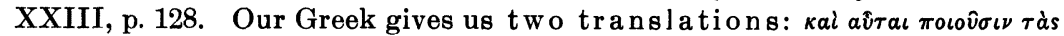

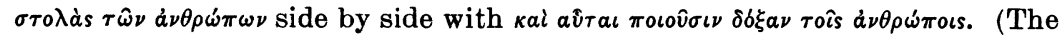
$\mathrm{L}$ text tries to escape this awkwardness by transposing the $\sigma \tau 0 \lambda$ ás clause in to vs. 16, where it is obviously out of place.) For the likelihood of such an

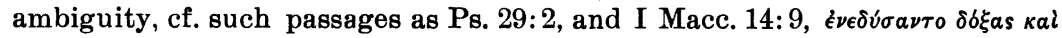
$\sigma \tau o \lambda \dot{a} s \pi 0 \lambda \epsilon \mu o v$ (where in the original Hebrew mistake for צבי (1).

e How is it possible to suppose that a Greek a u thor composing these lines would have perpetrated such an unnatural and unnecessary barbarism as

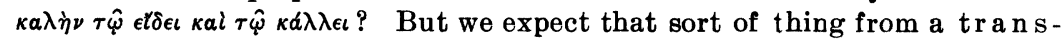
lator.

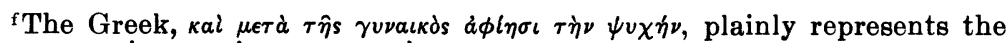
Aramaic which the translator misunderstood.

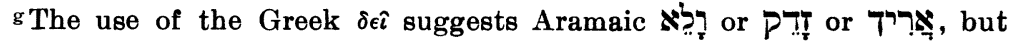
not any Hebrew idiom.

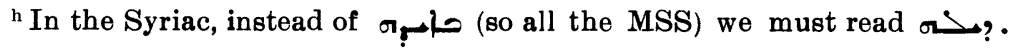


raid, and to rob and steal; he sails over seas and rivers, ${ }^{\text {a }}{ }^{24}$ faces the lion, and makes his way through the darkness. Then, when he has stolen, plundered, and robbed, he brings all to his love. ${ }^{25} \mathrm{~A}$ man loves his wife far more ${ }^{\mathrm{b}}$ than father or mother: ${ }^{26}$ for women, many have parted from their wits; for them they have been made slaves; ${ }^{27}$ yea, many have been ruined, have fallen, and perished, ${ }^{c}$ for woman's sake. ${ }^{28}$ And now, will you not believe me? Is not the king great in his power? Do not all countries fear to touch him? ${ }^{29}$ Yet I saw ${ }^{\mathrm{d}}$ the king's concubine, Apama, the daughter of Artabazos son of Thamasios, sitting at the king's right hand; ${ }^{30} \mathrm{I}$ saw her snatch the crown from his head, and place it upon her own; with her left hand she slapped the king. ${ }^{31}$ In spite of all this, ${ }^{f}$ the king gazed upon her with open mouth. As oft as she smiled upon him, he laughed; if she became vexed, he wheedled, that he might be restored to favor. ${ }^{32}$ Sirs, must not the women be mighty, seeing they do such things as these?

${ }^{33}$ Then the king and the nobles looked at one another. ${ }^{\mathrm{g}}$ Thereupon he went on ${ }^{\mathrm{h}}$ to speak of truth. ${ }^{34}$ Sirs, are not women

${ }^{a}$ Eis $\tau \grave{\eta} \nu \theta a ́ \lambda a \sigma \sigma a \nu \pi \lambda \epsilon \hat{\imath} \nu$ is not Greek; the $\epsilon i s$ merely reproduces an Aramaic ב. If ט was the verb used, we know from the Syriac that it was regularly construed with this preposition.

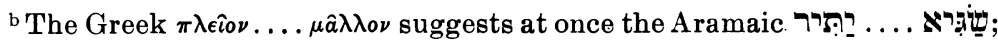
the Hebrew has no idiom which would fit exactly here.

c Greek $\dot{\eta} \mu a ́ \rho \tau o \sigma a \nu$, but we may be certain that this singularly feeble anticlimax did not exist in the original. The Syriac does not render by chooses a verb (صحص ) which may mean either "err" or "be ruined;" and doubtless some such word stood in the Aramaic.

d Guthe has: Und doch schauten sie (!; ihn.

e On this name, and the other names in the verse, see above. The Latin of the Lucca codex (Lagarde, Septuaginta-Studien, II, 17), mentioned above', has here: et Debannapenem [Lag. edits, Debanna pemen] filia Bezzachi . . . . concubina regis sedentem vidi circa regem. Lagarde did not attempt to explain this, but only observed that the latter part of this singular word ("des sonderbaren Worts") contained the name 'A $\pi \eta^{\prime} \mu \eta \nu$. The rest is simply a mutilated [vi]debam, which rendered the Greek $\epsilon \theta \epsilon \omega \rho o v \nu$. This Lucca text is derived from a close translation of the Lagarde Greek recension.

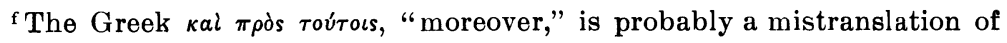

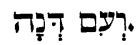

$\mathrm{g}$ There is no need to attempt, as Fritzsche and others have done, to explain

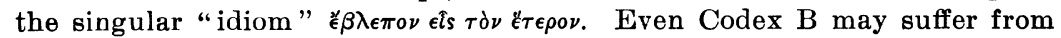

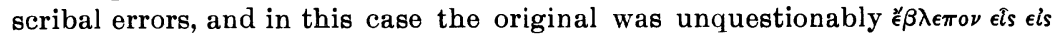
$\tau \dot{\tau} \nu \epsilon \tau \epsilon \rho \nu$ - this being the preposition with which the verb in this sense is most commonly construed. One $\epsilon$ s fell out by accident.

${ }^{\mathrm{h}} \mathrm{See}$ the note on $3: 16$. 
mighty? Great is the earth, and lofty the sky, and swift the sun in his course, for he rounds the circuit of the heavens, and returns again to his place in a single day. ${ }^{35} \mathrm{Is}$ not he great who does this? But ${ }^{a}$ truth is greatest and mightiest of all. ${ }^{b}{ }^{36}$ All the earth invokes truth, and the heavens praise her; and all created things ${ }^{c}$ totter and tremble . . . . ${ }^{\mathrm{d}}$ and with her ${ }^{\mathrm{e}}$ is no error ${ }^{\mathrm{f}}$ at all. ${ }^{37}$ Perverse is the wine, perverse is the king, perverse are women; perverse are all the children of men, and all their works, all such alike, if ${ }^{g}$ truth abide not in them; and in their perversity they shall perish. ${ }^{38}$ But truth endures, and grows ever stronger; yea, lives and prevails for ever and ever. ${ }^{39} \mathrm{With}$ her is ${ }^{\mathrm{h}}$ no

${ }^{a}$ Could any Greek writer, not a translator, have been content to use $\kappa a l$ for the conjunction both here and at the beginning of vs. 38 ?

b The addition of $\pi a \rho d$ to the comparative degree of the adjective probably translates יתיר מדת. Cf. the Syriac.

c"E 2 \%

${ }^{d}$ It seems probable that something is missing here, perhaps only a few words. What we have in our present text is not sufficient to give the third cla u se of the verse a satisfactory connection with its surroundings, nor to prepare the way for the last clause. We might imagine some such progress of the thought as this: "And all created things totter and tremble [before her, for she alone is perfect,] and with her is no error at all." It must be remembered that all our manuscripts and versions are derived from a single faulty Greek codex, which in turn represented a translation made from a more or less imperfect Aramaic text.

eThe only well attested reading is $\mu \epsilon \tau$ ' aivov, "with him." Thus both the Lagarde text and the Egyptian text (represented by the codices A, B, and their fellows). The reason for the choice of the masculine pronoun was of course the desire to find, or to introduce, the mention of God in this most important passage, especially after the seeming mention of him in the words

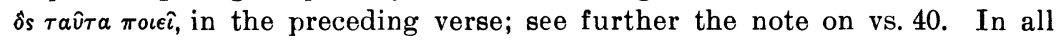
probability, Josephus had before him the reading $\mu \epsilon \tau$ ' aủrov̂; at all events, he adopts the interpretation which it embodies. Since the Greek translation was made after this story had become a part of the Chronicler's history, it is most likely that the translator himself chose the masculine pronoun here. But in the original, the suffix pronoun certainly referred to "Truth." The necessity of this is so obvious that some Greek codices and the Latin version have corrected accordingly.

${ }^{\mathrm{f}}$ It is a pity that we do not know what Aramaic words are rendered by $\dot{a} \lambda \hat{\eta} \theta \epsilon \iota a$ and $\dot{a} \delta \iota \kappa i a$, in these verses. Supposing the former to have been the latter would have been some such word as ערזָז (literally "crookedness").

g According to the conjecture already made; Vol. XXIII, p. 130.

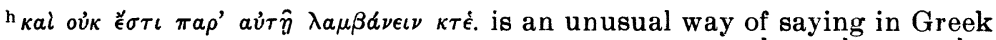
"She does not accept," etc. The original was רלא אתי לותה למסב אפיך. How natural this form of words is in Aramaic may be seen from Deut. 10: 17, where the Hebrew has simply לא רשא פמים, while the Targum replaces this by the same idiom which we have here. 
respect of persons, nor seeking of profit, ${ }^{a}$ but she executes judgment on $^{\mathrm{b}}$ all the evil and wicked. All approve her acts, ${ }^{(40)}$ and in her judgment there is no injustice. ${ }^{.}{ }^{40}$ And hers ${ }^{d}$ is the might, and the kingdom, and the power, and the majesty for ever and ever. ${ }^{\mathrm{e}}$ Blessed of God is ${ }^{\mathrm{f}}$ truth! ${ }^{41}$ And he ceased speaking. ${ }^{\mathrm{g}}$ Then all the people cried out, saying, Great is truth, and mightiest of all!

${ }^{42}$ Then the king said to him: Ask what thou wilt, above what was prescribed, and we will give it thee, since thou art proved wisest; and thou shalt sit beside me, and be called my kinsman.

\section{THE INTERPOLATOR'S ADDITIONS}

It is most likely that the story in its original form ended at this point (the end of verse 42) and in just this way. It is true that the king is made to say: "Ask what thou wilt, above what was prescribed, and we will give it thee;" but it is quite probable that this was merely a picturesque oriental flourish, and that the hearers or readers were left to imagine for themselves what,

a $\Delta \iota d ́ \phi o \rho a$ here in the post-classical sense "rewards" or "gifts;" the meaning being that Truth, as judge, neither regards persons nor takes bribes.

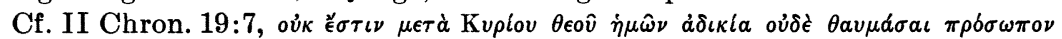
oú $\delta \hat{\epsilon} \lambda a \beta \epsilon \hat{\nu} \delta \hat{\omega} \rho a$, a parallel which is interesting in view of the fact that the two passages are presumably quite independent of each other.

${ }^{\mathrm{b}}$ The Greek ámo translating $7 \mathrm{~s}$. On the Aramaic idiom here, found also Ezra 7:26, see Vol. XXIII, p. 130.

c On the reading of the Hexaplar Syriac in this clause, eee Vol. XXIII, p. 69.

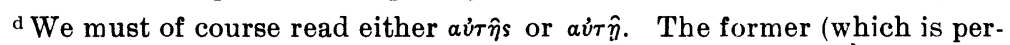
haps more likely to have been the original, if the Aramaic was דילה) is the reading of the Lagarde text; the latter that of the Egyptian recension.

e This sentence may well have been the origin of the doxology which has been appended to the Lord's Prayer in Matt. 6:13.

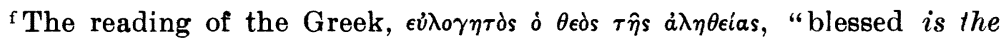
God of truth," is manifestly unsuitable. If the speaker had intended to advance from the praise of truth to that of God, he would have needed to begin sooner. The least that we could require of him would be that he should indicate the relation of (rod to truth. Verse 41, moreover, ignores any ascription of praise to God in the closing words of the discourse. Evidently, our present reading is due to the same interpretation or redaction which found or introduced the mention of the deity in vss. 35 and 36 . The original was pre-

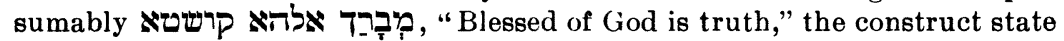
being employed in the manner familiar from the Old Testament. In all probability, the Greek translator is the one who should be held responsible for the misinterpretation both here and in vs. 36; see the note there. It is of course possible that the whole clause is a later addition.

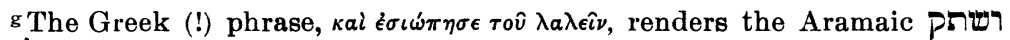

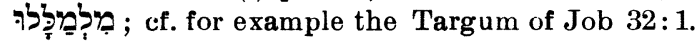


if anything, it was that the young soldier requested. Certain it is, at all events, that verse 42 as a whole was not written by the interpolator, for he would not have ended it in this way; the last clause only serves to interrupt his undertaking. If we suppose that the tale originally had another conclusion, which he has replaced by his own, it is not of the least use to try to conjecture what that conclusion was.

As has already been remarked, it was probably the interpolator himself who inserted the gloss, "this was Zerubbabel," in $4: 13$; and he now proceeds, with manifest skill, to effect the transition to the Chronicler's narrative of the returning Jews and the help given them by Cyrus. Only four verses $(43-47 a)$ are needed at this point, namely the following:

${ }^{43}$ Then he said to the king: Remember the vow which thou didst make, to build Jerusalem in the day when thou shouldst receive thy kingdom ${ }^{18}{ }^{44}$ and to send back all the vessels which were taken from Jerusalem, which Cyrus when he first ${ }^{19}$ conquered Babylon brought away, ${ }^{20}$ but vowed ${ }^{21}$ to return them thither; ${ }^{45}$ and thou didst promise to build the temple which the Edomites burned ${ }^{22}$ when Judea was laid waste by the Chaldeans. ${ }^{46}$ And now, this is the thing which I ask, my lord the king, and for which I make request of thee, since such munifcence is thine ${ }^{23} I$ ask that thou perform the vow which thou didst vow to the King of Heaven ${ }^{24}$ with thine own lips to perform. ${ }^{47}$ Then Darius the king arose, and kissed him; and | wrote for him letters, etc.

18 From the order of the words in the Greek, coupled with our knowledge of the closeness of this rendering, it is evident that the connection of clauses is that which $I$ have given in the translation: Darius had vowed to do these things when he should come to the throne. According to the interpolator, this feast at the Persian capital took place at or very near the beginning of Darius' reign. This is also made necessary by the sequel: the altar was built by the returned exiles "in the seventh month" (of the first year of Darius), I Esdr. $5: 46$; the foundation of the temple was first laid "in the second year in the second month," $5: 55$; and the interrupted work of building was renewed before the end of this same year, thanks to the efforts of the prophets Haggai and Zechariah, 6:1. All this chronology is flatly contradicted by $5: 6$, to be sure; see below, pp. $200 \mathrm{f}$.

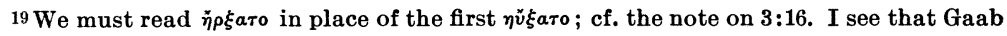
(cited in Fritzsche) has anticipated me in this conjecture.

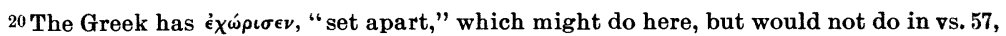
where it is used in a similar context. The reading $\dot{\epsilon} \xi \in \chi^{\omega} \omega \eta \sigma \epsilon \nu$, found in codex $A$, and

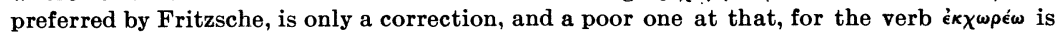
ordinarily intransitive. The interpolator's theory of the temple vessels was this: When Cyrus took Babylon, he carried away some of these vessels to Susa, with the other plunder; the rest of them, which were still in Babylon, he sent to Jerusalem by Sheshbazzar, promising to send the remainder (those in Susa) at some later time. See also vs. 57 and the note there. In both verses, 44 and 57 , the original had a verb which meant to "bring forth" or "carry away" (here probably

21 The voluit of the Latin version here must originally have been vovit.

22 Interesting as embodying the popular tradition ir Palestine in the second century B. c. 23 On the Aramaic text of this clause, see above, p. 134, note.

24 An unusual and interesting title; also vs. 58, Dan. 4:34 (cf. 5:23). 
At this point, the Chronicler's Hebrew narrative was reached. The verse began with the words: "And Cyrus the king wrote for him (i. e., Sheshbazzar) letters," etc. This the interpolator altered skilfully, as usual. Up to this point the Aramaic language had been used (see above, pp. 134 f.); now Hebrew took its place. The transition, it should be observed, was a particularly easy one, inasmuch as the vocabulary of this verse and of the verses immediately following is almost identically the same in the two languages. The Jewish reader of that day would not have been disturbed by the change, and, indeed, might not have noticed it at all until several verses of the Hebrew had been read.

By this first editorial insertion, the interpolator gave the Story of the Youths its connection with Jewish history. Darius the king is asked by the victorious youth to fulfil his promises, (1) to build Jerusalem; (2) to send to Jerusalem the temple vessels which Cyrus had carried from Babylon to Susa, but had promised to restore to the Jews; (3) to build the temple in Jerusalem. It is noteworthy, and another striking illustration of the self-restraint of the interpolator, that in these verses not a word is said regarding the expedition of Zerubbabel and his friends to Jerusalem! This youth was one of the three bodyguardsmen of the king; he does not even ask for leave of absence, however, but takes himself off (vs. 61) as a matter of course. The company of Jews which now sets out from Babylonia is a very large one; but the youth does not request, nor suggest, that they be allowed to go, nor is any formal permission given. The way in which it is simply taken for granted, in vs. 47 , that "he" and "those with him" are going up to people Jerusalem, is one of the most satisfactory bits of incidental evidence that the juncture of the patch with the main narrative - the continuation of Ezra 1:1-11comes at just this point. Verses $47 \mathrm{ff}$. cannot possibly be regarded as the sequel of $43-46$.

A second patch was necessary after verse 56, at the point where the prescriptions of the king for the returning exiles came to an end. First of all, the interpolator had need to introduce mention of his second instalment of temple vessels, in accordance with verse 44. Moreover, the need of some transition from the palace in Susa to the Jews in Babylonia, mentioned in the next verse of the Chronicler, was sufficiently obvious. The inter- 
polator fills these needs easily, as usual. He also improves the opportunity, in narrating the exit of the youth from the palace, to introduce a little of the religious element which is so noticeably lacking in the preceding tale. The five verses (originally Hebrew) which constitute this patch read as follows:

${ }^{57}$ And he sent forth all the vessels which Cyrus had brought ${ }^{25}$ from Babylon; and all which Cyrus had ordered to be made, he himself commanded to make ${ }^{26}$ and send to Jerusalem.

${ }^{58}$ And when the youth went forth, lifting up his face to heaven toward Jerusalem, ${ }^{27}$ he blessed the King of Heaven, ${ }^{28}$ saying: ${ }^{59}$ From thee is victory, and from thee wisdom, ${ }^{29}$ thine is the glory, and $I$ am thy servant. ${ }^{60}$ Blessed art thou, who hast given me wisdom; and to thee I give thanks, $O$ Lord of our fathers. ${ }^{61}$ So he took the letters and went forth, ${ }^{30}$ and came to Babylon and told all his brethren. $\mid{ }^{62}$ And they blessed the God of their fathers, etc.

With verse 62 the Chronicler's narrative is resumed; and after this point the work of the interpolator's hand is seen only in 5:2, where the name "Cyrus" is changed to "Darius," and in 5:6, where both this change of name and also other alterations have been made (see below).

This latter verse, 5:6, is a good illustration of the difficulties with which the interpolator was confronted in his attempt to make the best of an impossible task. In some particulars, to be sure, his expanded version of the history might have seemed even more plausible than that of the Chronicler (it has been preferred in recent times, for instance, by so acute a scholar as Sir Henry Howorth) ${ }^{31}$ Thus, in the Chronicler's narrative the career of Zerubbabel is extended over more than a hundred years, from the beginning of the reign of Cyrus down to the first years of the reign of Darius II Nothus. ${ }^{32}$ It is, of course, unfair to impose our chronology upon the Chronicler, who not only made the reign of Darius I Hystaspis precede that of Cyrus, but also may have thought the reigns of Xerxes and Artaxerxes I shorter than we

25 The Greek has éxw on verse 44.

26 The Hebrew text here was very likely corrupt.

27 So also in the contemporaneous writings Dan. 6:11; Tobit 3:11f.

28 See the note on verse 46.

29 If the author of the Story of the Youths were writing this verse, we should expect him at least to add: "and with thee is truth!"

30 Namely, from Susa. I do not know that any commentator has ever tried to explain the words, "and came to Babylon," in this verse.

31 See also Marquart, Fundamente, pp. 42, 65.

32 See above, p. 178. 
know them to have been; but even so, his life of Zerubbabel is too long, and the scenes in it are much too far apart. ${ }^{33}$ But in the interpolated edition of the history, the dramatic unity is as perfect as any one could wish. Zerubbabel, the young Hebrew, is one of the most trusted attendants of the Persian king. Sent by him to Jerusalem with a large company, as a reward for his wise discourse, he restores the Jewish community; builds the altar of burnt-offerings; lays the foundation of the temple; repulses the wicked Samaritans and their allies; is stopped by them in his work, but begins it again almost immediately, before the end of the same "second year;" secures an edict of the king in his favor; and finishes the work in triumph. And all this happens within the space of six years! It is no wonder that this revised version of the history became so popular as to supplant completely the older version. But the interpolator's triumph was a very precarious one, for his improved story of Zerubbabel contained such contradictions as could never stand the test of a critical examination. Either he was not fully aware of these contradictions (interpolators very often fail to see all the consequences of their work), or else he shared the current dislike of erasing the written word, and was willing to rest his fate on popular approval and elastic exegesis. At all events, he allowed such telltale verses as I Esdr. 5:53 b (=Ezra 3:7), 68 (=Ezra 4:3), 70 (=Ezra 4:5), and the date in I Esdr. 5: 6, to remain in their places. In I Esdr. $5: 70$, for example, after the narrative which tells how Zerubbabel and his companions, in the second year of their return to Jerusalem (verse 54), in the reign of Darius, began to build the temple, but were stopped by their enemies, we read that these enemies "hindered the completion of the building during all the lifetime of king Cyrus, so that the building was stopped until the reign of king Darius ! ${ }^{3 *}$ Here the only refuge of the interpolator would be in the very lame explanation that the verse was merely a retrospect, its meaning being that these enemies were able to stop the work of building from the time when the foundation was laid by Sheshbazzar down to the time of Darius. Even more troublesome is the verse I Esdr. 5:6, to which allusion has been made.

33 This was the Chronicler's own fault, to be sure, and the necessary result of his choosing to make Jeshua and Zerubbabel the leaders of his great "return" under king Cyrus. They were already known, from the prophecies of Haggai and Zechariah, to have flourished under a "Darius," who, from the chronology current among the Jews in the last three centuries B. c., could have been only Darius Nothus.

34 The text appears to be slightly corrupt here; cf. the Hebrew, and also 6:1 (=Ezra 5:1). 
This originally contained the Chronicler's date of the return from the exile: "in the second year of the reign of Cyrus king of Persia, in the month Nisan, on the first day of the month." The interpolator gave this a connection with the mention of Zerubbabel, just preceding, and made out of it: "who spoke wise words before Darius king of Persia, in the second year of his reign, in the month Nisan, on the first day of the month." But even with this alteration, the date is absolutely impossible in the interpolated history. There is no process, however violent, by which it can be brought into agreement with the dates which follow, in $5: 46,55,6: 1$. The interpolator may have seen this difficulty and defied it, but it is more likely that it escaped his notice. He was probably not especially interested in chronology, and found it easy to overlook such details as these.

In spite of its glaring contradictions, the interpolated edition of the history became the popular one, thanks to the discourses of the three youths and to the improved story of Zerubbabel, and in a short time had completely supplanted the original form; so completely, in fact, that not a trace of the uninterpolated work has come down to us, whether in manuscript or version, in Jewish or Christian tradition. ${ }^{35}$

35 As was shown above, pp. 138 f., our canonical Ezra is merely a mutilated recension of the interpolated book. This will be further demonstrated in the sequel. 